\title{
Bahan Ajar Interaktif Bermuatan Pendidikan Karakter pada Materi Sistem Pernapasan pada Manusia dan Hewan
}

\section{Ni Luh Putu Ema Widari ${ }^{*}$, I Gede Astawan², Made Sumantri ${ }^{3}$}

\author{
1,2,3 Pendidikan Dasar, Universitas Pendidikan Ganesha, Singaraja, Indonesia
}

\section{AR T I C L E I N F O}

Article history:

Received June 19, 2021

Revised June 20, 2021

Accepted July 30, 2021

Available online December 25, 2021

Kata Kunci:

Bahan Ajar Interaktif, Pendidikan Karakter

\section{Keywords:}

Interactive teaching materials, character education

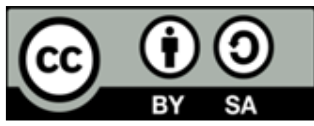

This is an open access article under the CC BY-SA license.

Copyright (@) 2021 by Author. Published by Universitas Pendidikan Ganesha.

\begin{abstract}
A B S T R A K
Kurangnya bahan ajar yang inovatif yang dapat meningkatkan semangat siswa dalam belajar. Selain itu pemanfaatan bahan ajar pendukung masih kurang, siswa hanya berpatokan pada buku siswa saja sebagai sumber belajar utama. Penelitian ini bertujuan untuk menciptakan bahan ajar interaktif bermuatan pendidikan karakter pada materi Sistem Pernapasan Manusia dan Hewan Kelas V. Jenis penelitian ini yaitu pengembangan dengan menggunakan prosedur ADDIE. Subjek uji coba penelitian yaitu 2 orang ahli media pembelajaran, 2 orang ahli desain pembelajaran, 2 orang guru, dan 9 orang siswa. Metode yang digunakan dalam mengumpulkan data yaitu observasi, wawancara dan angket. Instrumen yang digunakan dalam mengumpulkan data yaitu kuesioner. Teknik yang digunakan untuk menganalisis data yaitu analisis deskriptif kualitatif dan analisis deskriptif kuantitif. Hasil penelitian yaitu penilaian yang diberikan oleh ahli materi pembelajaran yaitu 3,86 (sangat baik), penilaian dari ahli media pelajaran yaitu 3,87 (sangat baik), penilaian dari ahli desain pelajaran yaitu 3,82 (sangat baik), hasil uji coba perorangan yaitu 3,93 (sangat baik), hasil uji coba kelompok kecil yaitu 3,85 (sangat baik). Jadi bahan ajar yang dikembangkan layak digunakan dalam proses pembelajaran. Implikasi penelitian ini yaitu produk yang dikembangkan dapat digunakan guru sebagai bahan ajar yang membantu siswa dalam belajar mandiri.
\end{abstract}

\section{A B S T R A C T}

Lack of innovative learning materials that can increase students' enthusiasm for learning. In addition, the use of supporting teaching materials is still lacking, students only rely on student books as the main learning resource. This study aims to create learning materials that contain character education on the Human and Animal Respiratory System Class $V$ material. This type of research is development using the ADDIE procedure. The subjects of the research trial were 2 learning media experts, 2 learning design experts, 2 teachers, and 9 students. The methods used in collecting data are observation, interviews and questionnaires. The instrument used in collecting data is a questionnaire. The technique used to analyze the data is descriptive qualitative analysis and descriptive quantitative analysis. The results of the study were the assessments given by the learning materials experts, namely 3.86 (very good), the assessments from the instructional media experts, namely 387 (very good), the assessments from the design experts, namely 3.82 (very good), the results of individual trials, namely 3.93 (very good), the result of the small group trial is 3.85 (very good). So teaching materials are suitable for use in the learning process. The implication of this research is that the product developed can be used by teachers as teaching materials that help students in independent learning.

\section{PENDAHULUAN}

Pendidikan dapat menumbuhkan serta mengembangkan potensi manusia yang unggul. Selain itu pendidikan dapat meningkatkan pembangunan yang membuat suatu negara menjadi unggul (Lase, 2019; Rudiyati, 2013). Melalui pendidikan seseorang akan menjadi cakap terampil serta memiliki moral yang baik (Wulandari et al., 2020; Yusuf, 2012). Pendidikan dasar adalah jenjang awal yang harus dilalui oleh seseorang untuk dapat melanjutkan ke jenjang selanjutnya. Hal ini yang menyebabkan pendidikan dasar 
memiliki peran penting untuk menanamkan nilai moral yang akan membentuk generasi unggul dan memiliki karakter yang kuat (Damanik \& Setiawan, 2016; Veronika, 2019; Zuliani et al., 2017). Pendidikan harus dipersiapkan dengan baik untuk menghadapi era globalisasi. Pendidikan akan menciptakan sumber daya manusia yang berkualitas (Rudiyati, 2013; Za'im, 2016). Salah satu jenjang pendidikan awal yang didapatkan oleh seseorang adalah sekolah dasar. Dalam proses pembelajaran diperlukan sebuah model serta media pembelajaran yang dapat mendukung aktivitas belajar (Diyantari et al., 2020; Rosdiana et al., 2013; Widiatmika et al., 2017). Hal ini bertujuan agar tujuan pembelajaran dan pendidikan dapat tercapai dengan maksimal. Dalam pelaksanaan pembelajaran para guru membutuhkan bahan ajar yang disesuaikan dengan karakteristik serta kebutuhan siswa yang nantinya akan membantu siswa dalam belajar (Asriani et al., 2017; Fadillah \& Jamilah, 2016; Purnomo \& Wilujeng, 2016). Pengunaan bahan ajar ini akan membantu proses pembelajaran. Bahan ajar yang baik sesuai dengan tujuan pembelajaran, menggunakan bahasa yang mudah dipahami oleh siswa, dan sesuai dengan perkembangan anak (Fadillah \& Jamilah, 2016; Purnomo \& Wilujeng, 2016).

Permasalahan yang terjadi saat ini yaitu kurangnya bahan ajar yang inovatif yang dapat meningkatkan semangat siswa dalam belajar (Qondias et al., 2019; Wati et al., 2014). Permasalahan yang sering terjadi di sekolah yang berkaitan dengan proses belajar mengajar adalah bahan ajar yang kurang bervariasi. Materi yang terdapat dalam setiap bahan ajar tidak sesuai dengan karakteristik siswa sehingga membuat siswa menjadi malas untuk membaca (Gafur, 2010; Martha \& Andini, 2019). Dalam pembelajaran IPA masalah yang sering dihadapi pada anak sekolah dasar yaitu penggunaan bahan ajar yang kurang menarik bagi siswa dan dalam pembelajaran tidak selalu menggunakan media pembelajaran (Mustika \& Ain, 2020; Purnomo \& Wilujeng, 2016). Apalagi saat ini pembelajaran di Indonesia telah berubah menjadi daring, karena dampak virus corona (Ayuni et al, 2021; Dewi, 2020; Sadikin \& Hamidah, 2020b). Perubahan pembelajaran ini akan mempengaruhi proses pembelajaran terutama di sekolah dasar karena pembelajarna daring belum dapat berjalan dengan efektif (Sadikin \& Hamidah, 2020a; H. Wulandari \& Purwanta, 2021). Hal ini dikarekan sistem daring masih dianggap sistem baru sehingga persiapan guru dalam pembelajaran daring ini masih kurang. Kurangnya persiapan guru dalam memfasilitasi siswa untuk belajar seperti falitas media dan bahan ajar menyebabkan siswa menggunakan buku sebagai sumber utama dalam belajar (Batubara \& Batubara, 2020; Fitriyani et al., 2020). Pembelajaran seharusnya dapat disajikan dengan baik sehingga menjadi daya tarik bagi siswa. Berdasarkan hasil wawancara dengan guru kelas V SDN 1 Semarapura Kangin, diketahui bahwa pemanfaatan bahan ajar pendukung masih kurang, siswa hanya berpatokan pada buku siswa saja sebagai sumber belajar utama. Hal ini terjadi dikarenakan kurangnya bahan ajar yang dapat digunakan sebagai sumber belajar tambahan untuk siswa dalam proses pembelajaran daring.

Solusi yang ditawarkan untuk meningkatkan semangat siswa dalam belajar yaitu dengan mengembangkan bahan ajar interaktif. Bahan ajar merupakan sesuatu yang berupa informasi yang digunakan untuk memudahkan siswa dalam belajar (Purnomo \& Wilujeng, 2016). Bahan ajar dapat dikembangkan dengan menarik sehingga siswa tertarik untuk belajar (Darmayasa et al., 2018; Wijayanti et al., 2016). Bahan ajar yang dapat digunakan oleh guru sangat beragam seperi bahan ajar cetak, bahan ajar audio, ataupun bahan ajar interaktif. Bahan ajar interaktif ini sangat penting dalam menunjang keberhasilan pembelajaran, sehingga harus disesuaikan dengan kebutuhan siswa dan kompetensi yang harus dicapai (Diantari et al, 2018; Imansari \& Sunaryantiningsih, 2017). Bahan ajar yang dapat meningkatkan semangat siswa yaitu bahan ajar berbantuan video. Video pembelajaran dapat mendukung kegiatan pembelajaran yang menarik karena menyajikan unsur audio dan visual pada siswa (Kawka et al., 2021; Saiboon et al., 2021). Mengembangkan bahan ajar yang dikombinasikan nilai karakter juga dapat meningkatkan mutu pendidikan serta pembentukan karakter. Pendidikan karakter harus ditanamkan sejak dini sehingga saat dewasa anak akan tumbuh dengan karakter yang baik (Maunah, 2015; Risabethe \& Astuti, 2017). Pendidikan karakter akan berdampak pada prestasi belajar siswa. Pendidikan karakter dipengaruhi juga oleh lingkungan. Pendidikan karakter akan meningkatkan akhlak mulia yang seimbang (Rahmadini, 2012; Santosa, 2014). Dengan adanya bahan ajar yang dikombinasikan dengan pendidikan karakter diharapkan akan mampu untuk menciptakan siswa yang mandiri serta meningkatkan pengetahuan, nilai karakter serta akhlak yang mulia (Dalimunthe, 2015). Hal ini yang menyebabkan pendidikan sangat penting didapatkan oleh setiap orang.

Temuan penelitian sebelumnya menyatakan bahwa bahwa modul interaktif dapat membantu belajar siswa serta meningkatkan semangat siswa untuk membaca (Neppala et al., 2018; R et al., 2021). Temuan penelitian sebelumnya juga menyatakan modul interaktif dapat meningkatkan hasil belajar siswa (Cloonan et al., 2020; McNamara et al., 2020). Belum adanya kajian mengenai bahan ajar interaktif bermuatan pendidikan karakter pada materi Sistem Pernapasan Manusia dan Hewan Kelas V. Kelebihan penelitian ini yaitu bahan ajar yang dikembangkan dikombinasikan dengan nilai karakter sehingga dapat membentuk karakter positif pada siswa. Selain itu, bahan ajar ini bersifat interaktif sehingga 
memudahkan siswa dalam belajar. Tujuan penelitian ini yaitu untuk menciptakan bahan ajar interaktif bermuatan pendidikan karakter pada materi Sistem Pernapasan Manusia dan Hewan Kelas V. Diharapkan bahan ajar interaktif bermuatan pendidikan karakter dapat memfasilitasi belajar siswa sehingga dapat meningkatkan motivasi belajar siswa.

\section{METODE}

Jenis penelitian ini yaitu research and development. Penelitian ini menggunakan model pengembangan ADDIE yang meliputi tahap analisis, desain, pengembangan, implementasi, dan evaluasi (Salim Nahdi \& Cahyaningsih, 2018). Model ADDIE dipilih karena memiliki 5 komponen yang saling berhubungan. Kelima tahapan ini, terstruktur secara sistematis yang artinya tahapan pertama sampai dengan tahapan yang kelima penerapannya harus sistematis tidak bisa diacak. Pada tahap analisis dilakukan analisis permasalahan yang terjadi di sekolah. Tahap desain dilakukan mendesain rancang bangun bahan ajar yang akan dikembangkan. Pada tahap pengembangan dilakukan mengembangkan bahan ajar dan uji validitas bahan ajar. Pada tahap implementasi dilakukan uji coba perorangan dan kelompok kecil. Subjek uji coba penelitian ini diuji oleh 2 orang ahli media pembelajaran, 2 orang ahli desain pembelajaran, 2 orang guru, dan 9 orang siswa. Metode yang digunakan dalam mengumpulkan data yaitu observasi, wawancara dan angket. Instrument yang digunakan dalam mengumpulkan data yaitu kuesioner. Adapun bagan desain penelitian disajikan Gambar 1 dan kisi-kisi instrument ahli disajikan pada Tabel 1, 2, 3 dan 4 .

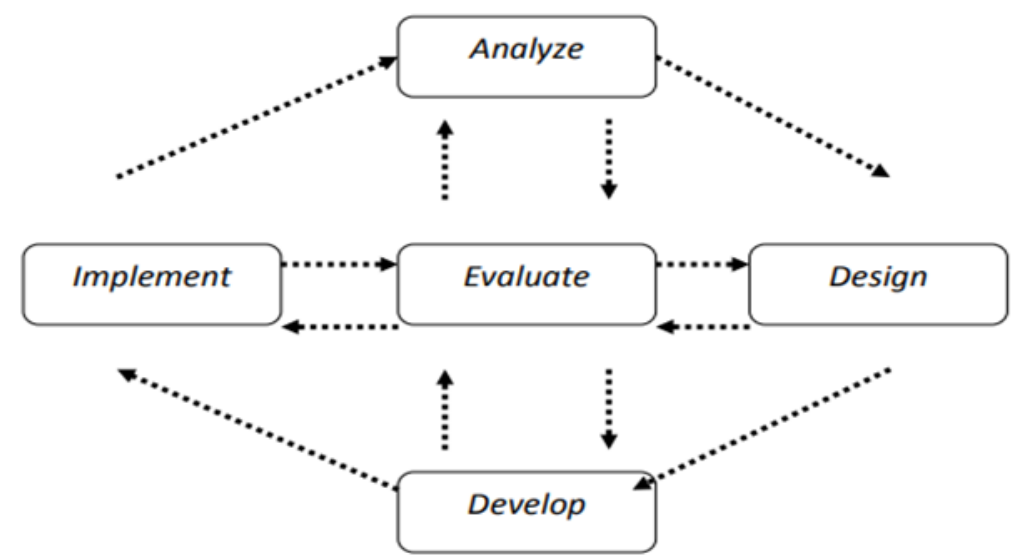

Gambar 1. Bagan Desain Pengembangan

Tabel 1. Kisi-Kisi Instrumen Ahli Materi Pelajaran

\begin{tabular}{|c|c|c|}
\hline No & Aspek & Indikator \\
\hline \multirow[t]{3}{*}{1.} & Aspek Pendahuluan & Kejelasan petunjuk belajar \\
\hline & & Keterkaitan bahan ajar interaktif dengan pembelajaran sebelumnya \\
\hline & & $\begin{array}{l}\text { Kejelasan kriteria capaian pembelajaran berkaitan dengan materi yang } \\
\text { dibahas }\end{array}$ \\
\hline \multirow[t]{2}{*}{2.} & Aspek isi & Keruntutan dan cakupan uraian materi \\
\hline & & Kesesuaian dan kemenarikan isi materi \\
\hline \multirow[t]{7}{*}{3.} & Pembelajaran & Kesesuaian materi dengan karakteristik siswa kelas $\mathrm{V}$ \\
\hline & & Kesesuaian struktur materi \\
\hline & & Antara tujuan dan tugas konsisten \\
\hline & & Kejelasan uraian materi \\
\hline & & Kesesuaian gambar dan video dengan materi \\
\hline & & Tingkat kesulitan materi disesuaikan dengan karakteristik siswa kelas V \\
\hline & & Keruntutan latihan soal sesuai dengan materi \\
\hline \multirow[t]{3}{*}{4.} & Aspek evaluasi & Kejelasan petunjuk pengerjaan soal/tes yang disusun \\
\hline & & Kualitas soal/tes yang terdapat dalam bahan ajar interaktif \\
\hline & & Ketepatan pemberian soal/tes \\
\hline 5. & Rangkuman & $\begin{array}{l}\text { Kualitas rangkuman yang ada dalam bahan ajar interaktif } \\
\text { Kelengkapan rangkuman }\end{array}$ \\
\hline
\end{tabular}


Tabel 2. Kisi-Kisi Instrumen Ahli Media Pelajaran

\begin{tabular}{lll}
\hline No & \multicolumn{1}{c}{ Aspek } & \multicolumn{1}{c}{ Indikator } \\
\hline 1 & Tampilan & Kejelasan judul dan petunjuk penggunaan bahan ajar interaktif \\
& & Keterbacaan layout yang memudahkan siswa belajar \\
& Ketepatan pemilihan warna background \\
& Kesesuaian pemilihan jenis huruf \\
& Kesesuaian pemilihan ukuran huruf \\
& Kejelasan tampilan video pendukung materi \\
& Kemenarikan tampilan gambar dalam bahan ajar interaktif \\
& Kesesuaian desain cover dengan materi \\
& Konsistensi tampilan \\
& Kemudahan penggunaan produk \\
& Penggunan bahasa dalam video yang mudah untuk dipahami siswa \\
& Penggunaan & Kesesuaian komponen bahan ajar interaktif dan aspek bahasa yang \\
& digunakan & \\
& & Kualitas dan kemenarikan materi yang terdapat dalam bahan ajar \\
& interaktif & Ketepatan pemberian feedback dan self-assessment atas input \\
& penggunaan & \\
\hline
\end{tabular}

(Sidiq \& Najuah, 2020)

Tabel 3. Kisi-Kisi Instrumen Ahli Desain

\begin{tabular}{lll}
\hline No & \multicolumn{1}{c}{ Aspek } & \multicolumn{1}{c}{ Indikator } \\
\hline 1 & Tujuan / Kompetensi & Rumusan tujuan pembelajaran \\
& & Kejelasan rumusan kompetensi dasar \\
& & Kejelasan rumusan indikator \\
& \multirow{3}{*}{ Karakteristik siswa } & Penyajian materi \\
& & Penggunaan kalimat \\
& Kesesuaian penggunaan bahasa \\
& Kesesuaian video pembelajaran \\
& & Ketepatan pemberian feedback atas jawaban siswa \\
& Metode & Ketepatan strategi belajar \\
& & Sistematika sajian \\
& Pemberian contoh \\
& Penyajian video pembelajaran \\
& Kesesuaian komponen bahan ajar interaktif \\
&
\end{tabular}

Tabel 4. Kisi-Kisi Instrumen Uji Perorangan dan Uji Kelompok Kecil

\begin{tabular}{|c|c|c|}
\hline No & Aspek & Indikator \\
\hline 1 & Visualisasi & a. Kemenarikan video pembelajaran \\
\hline \multirow[t]{3}{*}{2} & Penyajian Materi & a. Kemudahan memahami materi \\
\hline & & b. Kejelasan uraian materi \\
\hline & & c. Keseimbangan materi dengan evaluasi \\
\hline \multirow[t]{2}{*}{3} & Teks & a. Kualitas teks yang digunakan \\
\hline & & b. Kejelasan teks yang digunakan \\
\hline \multirow[t]{2}{*}{4} & Gambar & a. Kualitas gambar yang digunakan \\
\hline & & b. Kejelasan gambar yang digunakan \\
\hline 5 & Motivasi & a. Memberikan semangat atau motivasi dalam belajar \\
\hline 6 & Evaluasi & a. Kesusaian soal dengan materi \\
\hline
\end{tabular}

(Sidiq \& Najuah, 2020)

Instrumen yang sudah dirancang akan diuji validitasnya dengan menggunakan rumus Gregory. Hasil uji validitas instrumen materi penilaian bahan ajar interaktif bermuatan pendidikan karakter mendapatkan nilai 0,89 sehingga instrumen sangat relevan. Penelitian pengembangan ini menggunakan dua teknik yaitu teknik analisis deskriptif kualitatif dan teknik analisis deskriptif kuantitatif. Teknik 
analisis deskriptif kualitatif ini digunakan untuk mengolah data hasil review dari beberapa ahli materi dibidang Ilmu Pengetahuan Alam dan ahli media. Teknik analisis deskriptif kuantitatif digunakan untuk mengolah angka-angka atau nilai yang diperoleh melalui lembar penilaian.

\section{HASIL DAN PEMBAHASAN}

Hasil

Bahan ajar interaktif bermuatan pendidikan karakter pada materi Sistem Pernapasan Manusia dan Hewan Kelas V, dikembangkan dengan menggunakan prosedur ADDIE. Adapun tahapan pengembangan media yaitu sebagai berikut. Tahap pertama yaitu analisis. Tahap ini kegiatan yang dilaksanakan dengan menganalisis kurikulum, analisis kebutuhan dan analisis karakteristik peserta didik. Berdasarkan hasil analisis kebutuhan didapatkan bahwa masih banyak guru yang belum memiliki bahan ajar inovatif yang dapat merangsang siswa dalam belajar. Hal ini berdampak pada semangat belajar siswa yang rendah. Hasil analisis karakteristik siswa yaitu siswa sekolah dasar masih berada pada tahap operasional konkrit. Selain itu, siswa sangat menyukai penggunaan teknologi karena saat ini siswa sudah terbiasa menggunkan teknologi yang dapat membantu siswa dimanapun dan kapapun. Hal ini dikarenakan materi ini sulit dipahami oleh siswa dengan mudah. Hasil analisis kurikulum bahan ajar yang bahan ajar yang akan dikembangkan pada materi Pernapasan Manusia dan Hewan. Berdasarkan hasil analisis kurikulum maka dikembangkannya bahan ajar interaktif bermuatan pendidikan karakter pada pembelajaran IPA materi sistem pernapasan pada manusia dan hewan.

Tahap kedua yaitu desain. Pada tahap perancangan, dilakukan pembuatan prototype dan pembuatan instrumen bahan ajar interaktif bermuatan pendidikan karakter yang akan dikembangkan. Tahap ini dimulai dengan menentukan materi muatan IPA yang akan dikembangkan berdasarkan hasil analisis yang telah dilakukan. Selanjutnya disusun rancangan bahan ajar interaktif bermuatan pendidikan karakter. Adapun rancangan bahan ajar yang dilakukan adalah penyusunan instrumen penilaian bahan ajar, pembuatan desain background menggunakan aplikasi Microsoft Word. Adapun rancang bangun bahan ajar interaktif disajikan pada Gambar 2. Tahap ketiga yaitu pengembangan. Kegiatan yang dilakukan yaitu pengumpulan sumber referensi untuk mengembangkan materi, membuat gambar-gambar ilustrasi, bagan-bagan dan yang lainnya. Kemudian mengembangkan produk yang sesungguhnya sesuai dengan storyboard yang telah dibuat. Adapun media yang telah dikembangkan tersaji pada Gambar 3.

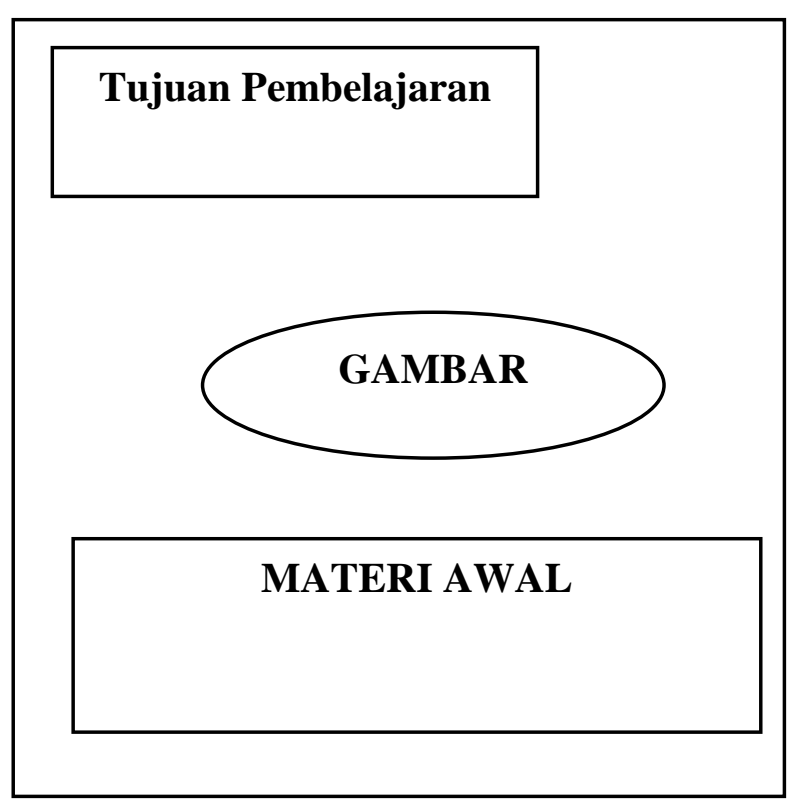

Gambar 2. Rancang Bangun Produk



Gambar 3. Bahan Ajar Interaktif

Setelah Bahan ajar interaktif bermuatan pendidikan karakter pada materi Sistem Pernapasan Manusia dan Hewan Kelas, maka selanjutnya yaitu validasi produk yang akan dinilai oleh para ahli Adapun hasil penilaian Bahan ajar interaktif bermuatan pendidikan karakter pada materi Sistem Pernapasan Manusia dan Hewan Kelas disajikan pada Tabel 5. 
Tabel 5. Hasil Uji Validasi para Ahli

\begin{tabular}{|c|c|c|c|}
\hline No & Para Ahli & Nilai & Kategori \\
\hline 1 & Ahli materi pelajaran & 3,86 & Sangat baik \\
\hline 2 & Ahli media pembelajaran & 3,87 & Sangat baik \\
\hline 3 & Ahli desain pembelajaran & 3,82 & Sangat baik \\
\hline 4 & Hasil uji coba perorangan & 3,93 & Sangat baik \\
\hline 5 & Hasil uji coba kelompok kecil & 3,85 & Sangat baik \\
\hline
\end{tabular}

Berdasarkan hasil analisis data, penilaian yang diberikan oleh ahli materi pelajaran yaitu 3,86 sehingga mendapatkan kategori sangat baik. Hasil analisis data penilaian yang diberikan oleh ahli media pelajaran yaitu 3,87 sehingga mendapatkan kategori sangat baik. hasil analisis data penilaian yang diberikan oleh ahli desain pelajaran yaitu 3,82 sehingga mendapatkan kategori sangat baik. Penilaian berdasarkan hasil uji coba perorangan yaitu 3,93 sehingga mendapatkan kategori sangat baik. Penilaian berdasarkan hasil uji coba kelompok kecil yaitu 3,85 sehingga mendapatkan kategori sangat baik. Berdasarkan saran dan komentar yang diberikan oleh para ahli materi dinyatakan bahwa dalam bahan ajar interaktif perlu ditambahkan link google form untuk siswa mengerjakan latihan soal sehingga tampak adanya interaktif antara guru dan siswa, jenis tulisan lebih disesuaikan lagi dengan background agar tidak merusak mata, menambahkan gambar-gambar asli pada materi bahan ajar interaktif. Adapun hasil revisi Bahan ajar interaktif bermuatan pendidikan karakter pada materi Sistem Pernapasan Manusia dan Hewan Kelas disajikan pada Gambar 4.
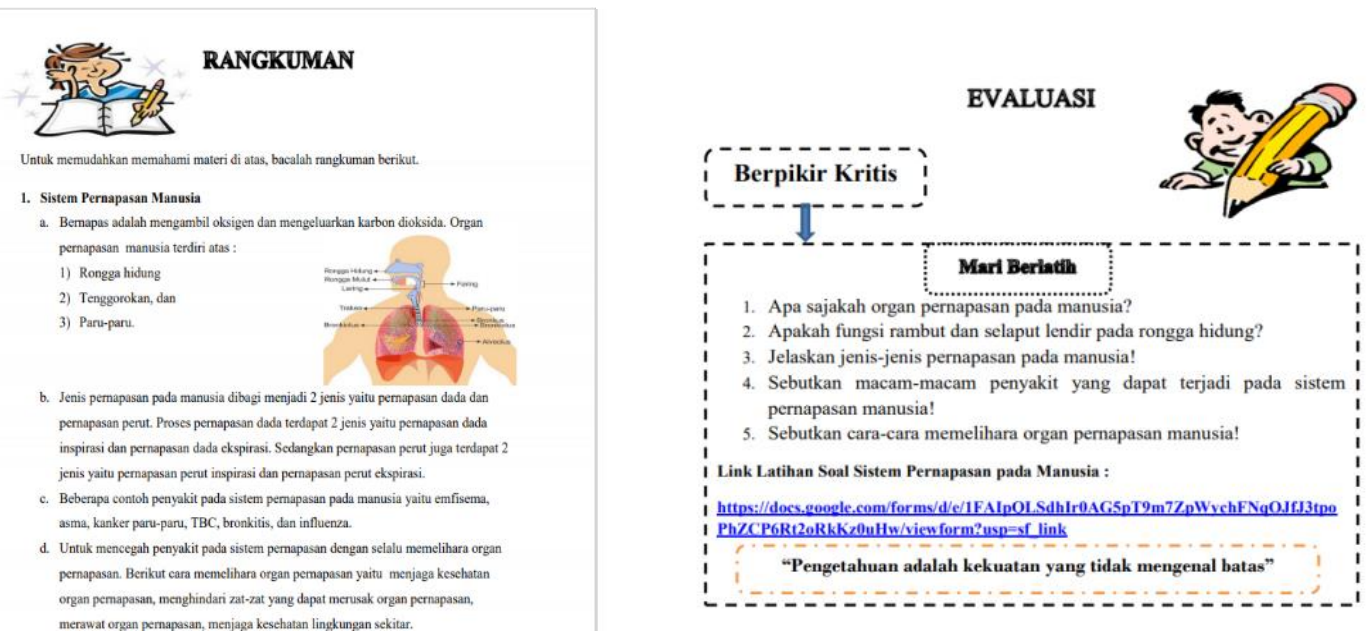

\section{Pembahasan}

Gambar 4. Hasil Revisian Bahan Ajar Interaktif

Hasil analisis menemukan bahwa bahan ajar interaktif bermuatan pendidikan karakter pada materi Sistem Pernapasan Manusia dan Hewan mendapatkan kategori sangat baik dan layak digunakan dalam proses pembelajaran. Adapun aspek-aspek yang dinilai, sehingga tercapainya kualifikasi sangat baik yaitu, aspek pendahuluan, aspek isi, aspek pembelajaran, aspek evaluasi dan aspek rangkuman. Aspek materi yang disajikan dalam bahan ajar interaktif yang dikembangkan telah dipaparkan dengan jelas, menarik, serta sesuai dengan tujuan pembelajaran. Tujuan pembelajaran pada bahan ajar interaktif sudah sesuai dengan kompetensi dasar dan indicator. Bahan ajar interaktif bermuatan pendidikan karakter pada materi Sistem Pernapasan Manusia dan Hewan layak digunakan dalam proses pembelajaran disebabkan oleh beberapa faktor yaitu sebagai berikut. Pertama, Bahan ajar interaktif bermuatan pendidikan karakter pada materi Sistem Pernapasan Manusia dan Hewan layak digunakan karena dapat merangsang siswa dalam belajar. Bahan ajar ini interaktif ini sangat menarik yang didalamnya juga disaikan video pembelajaran sehingga dapat merangsang belajar siswa. Bahan ajar yang menarik akan meningkatkan semangat siswa dalam belajar (Lee \& Osman, 2012; Maloney et al., 2016). Materi yang disajikan pada bahan ajar menarik yang disertai dengan contoh dan gambar sehingga meningkatkan minat siswa dalam membaca. Gambar dapat menarik minat siswa dalam belajar (Dianawati, 2019; Mardati et al., 2015; Umbara et al., 2020). Bahan ajar ini dikombinasikan dengan beberapa media seperti media audio, video, teks, dan grafik yang bersifat interakti sehingga juga akan memudahkan siswa dalam belajar. Media pembelajaran yang mudah digunakan akan membantu siswa 
dalam belajar serta merangsang minat siswa (Amaruddin et al., 2020; Fadhli, 2015; Hardiyanti et al., 2019). Bahan ajar interaktif ini sangat membantu siswa dalam belajar, karena bahan ajar tersebut mudah diakses dan disebarluaskan melalui handphone. Bahan ajar juga dapat menjadi media pembelajaran karena memuat rangkuman materi yang akan diajarkan kepada siswa (Putri et al., 2020; Yulisari, 2013).

Kedua, Bahan ajar interaktif bermuatan pendidikan karakter pada materi Sistem Pernapasan Manusia dan Hewan layak digunakan karena memudahkan siswa dalam menyerap informasi. Aspek materi yang disajikan dalam bahan ajar interaktif yang dikembangkan telah dipaparkan dengan jelas, menarik, serta sesuai dengan tujuan pembelajaran. Bahan ajar yang dikembangkan sesuai dengan karakteristik materi akan memudahkan siswa dalam memahami pembelajaran (Imansari \& Sunaryantiningsih, 2017; Kimianti \& Prasetyo, 2019; Wijayanti et al., 2016). Tujuan pembelajaran pada bahan ajar interaktif sudah sesuai dengan kompetensi dasar dan indikator. Selain itu, bahasa yang digunakan dalam bahan ajar interaktif sudah sesuai dengan karakteristik peserta didik. Penggunaan bahasa yang mudah dipahami siswa juga akan membantu siswa dalam memahami materi pembelajaran (Diantari et al., 2018; Sidiq \& Najuah, 2020). Pada bahan ajar interaktif ini juga berisikan contoh ilustrasi yang semakin membuat siswa mudah memahami materi pembelajaran. Ilustrasi atau pemberian contoh akan memudahkan siswa dalam mencerna informasi yang disajikan pada media sehingga hal ini berdampak pada pemahaman siswa yang semangin meningkat (Aryawan et al., 2018; Darmayasa et al., 2018; Suhaida \& Fadillah, 2019).

Temuan penelitian sebelumnya juga menyatakan bahan ajar interaktif memudahkan siswa dalam menyerap informasi (Ishikawa et al, 2011; Velan et al. 2015). Temuan penelitian lainnya juga menyatakan bahwa bahan ajar akan meningkatkan dan memotivasi siswa dalam belajar (Fadillah \& Jamilah, 2016; Purnomo \& Wilujeng, 2016). Kelebihan media pembelajaran ini yaitu bahan ajar yang menarik dan di dalam bahan ajar terdapat video pembelajaran beserta latihan soal melalui google form maupun latihan soal yang ada dalam bahan ajar. Di dalam bahan ajar ini juga terdapat pendidikan karakter yang baik, agar nantinya siswa dapat mengambil nilai positif dari bahan ajar interaktif ini. Keterbatasan penelitian ini yaitu penelitian hingga validitas dari bahan ajar dan belum mampu melihat dari segi efektifitas. Kontribusi penelitian ini yaitu dengan adanya bahan ajar ini akan membantu guru dalam menyampaikan informasi kepada siswa dengan mudah. Implikasi dalam penelitian ini, yaitu dihasilkannya bahan ajar interaktif bermuatan pendidikan karakter pada pembelajaran IPA materi sistem pernapasan pada manusia dan hewan dapat digunakan oleh guru sebagai bahan ajar yang membantu belajar siswa. Bahan ajar interaktif ini bermuatan pendidikan karakter sehingga siswa akan dapat mengambil nilai positif dari bahan ajar interaktif ini.

\section{SIMPULAN}

Bahan ajar interaktif bermuatan pendidikan karakter pada materi Sistem Pernapasan Manusia dan Hewan mendapatkan kategori sangat baik sehingga layak diterapkan dalam proses pembelajaran karena dapat meningkatkan motivasi siswa dalam belajar. direkomendasikan kepada guru untuk menggunakan bahan ajar interaktif yang akan membantu siswa dalam belajar mandiri.

\section{DAFTAR PUSTAKA}

Amaruddin, H., Atmaja, H. T., \& Khafid, M. (2020). Peran Keluarga Dan Media Sosial Dalam Pembentukan Karakter Santun Siswa Di Sekolah Dasar. Jurnal Pendidikan Karakter, 10(1). https://doi.org/10.21831/jpk.v10i1.30588.

Aryawan, Sudatha, \& Sukmana. (2018). Pengembangan E-Modul Interaktif Mata Pelajaran IPS Di Smp Negeri 1 Singaraja. Jurnal Edutech Undiksha, 6(2), 180-191. http://dx.doi.org/10.23887/jeu.v6i2.20290.

Asriani, P., Sa'dijah, C., \& Akbar, S. (2017). Bahan Ajar Berbasis Pendidikan Karakter Untuk. Jurnal Pendidikan: Teori, Penelitian, Dan Pengembangan, 2(11), 1456-1468. http://dx.doi.org/10.17977/jptpp.v2i11.10160.

Ayuni, D., Marini, T., Fauziddin, M., \& Pahrul, Y. (2020). Kesiapan Guru TK Menghadapi Pembelajaran Daring Masa Pandemi Covid-19. Jurnal Obsesi: Jurnal Pendidikan Anak Usia Dini, 5(1), 414. https://doi.org/10.31004/obsesi.v5i1.579.

Batubara, H. H., \& Batubara, D. S. (2020). Penggunaan Video Tutorial untuk Mendukung Pembelajaran Daring di Masa Pandemi Virus Corona. Jurnal Madrasah Ibtidaiyah, 5(2), 78-84. http://dx.doi.org/10. 31602/muallimuna.v5i2.2950.

Cloonan, M. R., Cloonan, D. J., Schlitzkus, L. L., \& Fingeret, A. L. (2020). Learners with Experience in Surgical Scrub Benefit from Additional Education with an Interactive E-Learning Module. Journal of the 
American College of Surgeons, 4(2). https://doi.org/10.1016/j.jamcollsurg.2020.08.521.

Dalimunthe, R. A. (2015). Strategi dan Implementasi Pelaksanaan Pendidikan Karakter di SMP N 9 Yogyakarta. Jurnal Pendidikan Karakter, 1(1). https: //doi.org/10.21831/jpk.v0i1.8616.

Damanik, M. R., \& Setiawan, D. (2016). Pengembangan Penilaian Autentik Berbasis Karakter Pada Ranah Keterampilan Di Fakultas Ilmu Sosial Universitas Negeri Medan. Jurnal Pendidikan Ilmu-Ilmu Sosial, 8(2). .https://doi.org/10.24114/jupiis.v8i2.5150.

Darmayasa, I. K., Jampel, N., \& Simamora, A. H. (2018). Pengembangan E-Modul Ipa Berorientasi Pendidikan Karakter Di Smp Negeri 1 Singaraja. Jurnal Edutech Undiksha, 6(1), 53-65. .http://dx.doi.org/10.23887/jeu.v6i1.20267.

Dewi. (2020). Dampak COVID-19 terhadap Implementasi Pembelajaran Daring di Sekolah Dasar. Jurnal Edukatif Ilmu Pendidikan, 2(1). https://doi.org/10.31004/edukatif.v2i1.89.

Dianawati, E. P. (2019). Pengaruh Media Tebak Gambar dan Talking Stick Terhadap Motivasi Belajar Siswa. Jurnal Ilmiah UNY, 1(1). https://doi.org/10.21831/jwuny.v1i1.26855.

Diantari, Damayanthi, Sugihartini, \& Wirawan. (2018). Pengembangan E-modul berbasis Mastery Learning untuk Mata Pelajaran KKPI Kelas XI. Jurnal Nasional Pendidikan Teknik Informatika (Janapati), 7(1), 33-48. http://dx.doi.org/10.23887/janapati.v7i1.12166.

Diyantari, I. A. K. D., Wiyasa, N., \& Manuaba, S. (2020). Model Snowball Throwing Berbantuan Media Pop Up Book Berpengaruh Terhadap Kompetensi Pengetahuan Ipa. Jurnal Ilmiah Pendidikan Profesi Guru, 3(1), 9-21. http://dx.doi.org/10.23887/jippg.v3i1.26973.

Fadhli, M. (2015). Pengembangan Media Pembelajaran Berbasis Video Kelas IV Sekolah Dasar. Jurnal Dimensi Pendidikan Dan Pembelajaran, 3, 24-29. http://dx.doi.org/10.24269/dpp.v3i1.157.

Fadillah, \& Jamilah. (2016). Pengembangan Bahan Ajar Struktur Aljabar Untuk Meningkatkan Kemampuan Pembuktian Matematis Mahasiswa. Cakrawala Pendidikan, 35(1), 106-108. https://doi.org/10.21831/cp.v1i1.8379.

Fitriyani, Y., Fauzi, I., \& Sari, M. Z. (2020). Motivasi Belajar Mahasiswa Pada Pembelajaran Daring Selama Pandemik Covid-19. Profesi Pendidikan Dasar, 7(1), 121-132. https://doi.org/10.23917/ppd.v7i1.10973

Gafur, A. (2010). Konsep, Prinsip, dan Prosedur Pengembangan Modul Sebagai Bahan Ajar. Jurnal Civics Media Kajian Kewarganegaraan, 7(1). https://doi.org/10.21831/civics.v7i1.3445.

Hardiyanti, Y., Husain, M. S., \& Nurabdiansyah. (2019). Perancangan Media Pengenalan Warna Untuk Anak Usia Dini. Jurnal Imajinasi Seni Dan Pendidikan, 2(2). https://doi.org/10.26858/i.v2i2.9553.

Imansari, N., \& Sunaryantiningsih, I. (2017). Pengaruh Penggunaan E-Modul Interaktif Terhadap Hasil Belajar Mahasiswa Pada Materi Kesehatan dan Keselamatan Kerja. VOLT : Jurnal Ilmiah Pendidikan Teknik Elektro, 2(1), 11-16. http://dx.doi.org/10.30870/volt.v2i1.1478.

Ishikawa, J., Fujita, Y., Maeda, Y., Furuta, H., \& Ikawa, Y. (2011). GNRA/receptor interacting modules: Versatile modular units for natural and artificial RNA architectures. Methods, 54(2). https://doi.org/10.1016/j.ymeth.2010.12.011.

Kawka, M., MH.Gall, T., Fang, C., Liu, R., \& Jiao, R. (2021). Intraoperative video analysis and machine learning models will change the future of surgical training. Intelligent Surgery, 1(1). https://doi.org/10.1016/j.isurg.2021.03.001.

Kimianti, \& Prasetyo. (2019). Pengembangan E-Modul IPA Berbasis Problem Based Learning Untuk Meningkatkan Literasi Sains Siswa. Kwangsan Jurnal Teknologi Pendidikan, 7(2). https://doi.org/10.31800/jtp.kw.v7n2.p91--103.

Lase, D. (2019). Pendidikan di Era Revolusi Industri 4.0. Jurnal Ilmiah Teknologi, Pendidikan, Sains, Humaniora Dan Kebudayaan, 1(1), 28-43. https://doi.org/10.36588/sundermann.v1i1.18

Lee, T. T., \& Osman, K. (2012). Interactive Multimedia Module in the Learning of Electrochemistry: Effects on Students' Understanding and Motivation. Procedia - Social and Behavioral Sciences, 46. https://doi.org/10.1016/j.sbspro.2012.05.295.

Maloney, E., S.Hippe, D., Paladin, A., Felix, \& Alice. (2016). Musculoskeletal Ultrasound Training for Radiology Residents: Lecture Versus Interactive Learning Modul. Academic Radiology, 23(7). https://doi.org/10.1016/j.acra.2015.11.018.

Mardati, Asih, \& Wangit. (2015). Pengembangan Media Permainan Kartu Gambar Dengan Teknik Make A Match Untuk Kelas 1 SD. Jurnal Prima Edukasia, 3(2), 120- 132. https://doi.org/10.21831/jpe.v3i2.6532.

Martha, nia ulfa, \& Andini, novita pri. (2019). Pengembangan Bahan Ajar Mata Pelajaran Bahasa Indonesia Berbasis Cerita Rakyat Kabupaten Banjarnegara. Jurnal Inovasi Pembelajaran, 5(2). https://doi.org/10.22219/jinop.v5i2.9992.

Maunah, B. (2015). Implementasi Pendidikan Karakter dalam Pembentukan Kepribadian Holistik Siswa. Jurnal Pendidikan Karakter, 1(1). https://doi.org/10.21831/jpk.v0i1.8615. 
McNamara, J., Sweetman, S., Connors, P., Lofgren, I., \& Greene, G. (2020). Using Interactive Nutrition Modules to Increase Critical Thinking Skills in College Courses. Journal of Nutrition Education and Behavior, 5(4). https://doi.org/10.1016/j.jneb.2019.06.007.

Mustika, D., \& Ain, S. Q. (2020). Peningkatan Kreativitas Mahasiswa Menggunakan Model Project Based Learning dalam Pembuatan Media IPA Berbentuk Pop Up Book. Jurnal Basicedu, 4(4), 1167-1175. https://doi.org/10.31004/basicedu.v4i4.518.

Neppala, P., Sherer, M. V., Larson, G., Bryant, A. K., Panjwani, N., Murphy, J. D., \& Gillespie, E. F. (2018). An Interactive Contouring Module Improves Engagement and Interest in Radiation Oncology Among Preclinical Medical Students: Results of a Randomized Trial. Practical Radiation Oncology, 8(4), e190-e198. https://doi.org/10.1016/j.prro.2018.01.001.

Purnomo, H., \& Wilujeng, I. (2016). Pengembangan Bahan Ajar dan Instrumen Penilaian IPA Tema Indahnya Negeriku Penyempurnaan Buku Guru dan Siswa Kurikulum 2013. Jurnal Prima Edukasia, 4(1), 67-68. https://doi.org/10.21831/jpe.v4i1.7697.

Putri, D. K., Handayani, M., \& Akbar, Z. (2020). Pengaruh Media Pembelajaran dan Motivasi Diri terhadap Keterlibatan Orang Tua dalam Pendidikan Anak. Jurnal Obsesi : Jurnal Pendidikan Anak Usia Dini, 4(2). https://doi.org/10.31004/obsesi.v4i2.418.

Qondias, D., Winarta, \& Siswanto. (2019). Pengembangan Bahan Ajar Berbasis Pendekatan Saintifik pada Mata Kuliah Metodologi Penelitian. Jurnal Penelitian Dan Pengembangan Pendidikan, 3(2), 145-148. https:// doi.org/10.23887/jppp.v3i2.17393.

R, J. V. C. I., Liu, X., Kong, J., Jiang, M., \& Li, S. (2021). Interactive information module for person reidentification. Journal of Visual Communication and Image Representation, 75(November 2019), 103033. https://doi.org/10.1016/j.jvcir.2021.103033.

Rahmadini, A. (2012). Pemberdayaan Pembelajaran Materi Ajar Identifikasi Sifat-Sifat Bangun Datar Bagi Pengembangan Nilai Karakter Berpikir Kritis dan Logis. Kreano Jurnal Matematika Kreatif-Inovatif, 3(1). https://doi.org/10.15294/kreano.v3i1.2609.

Risabethe, \& Astuti. (2017). Pengembangan Media Pembelajaran Untuk Meningkatkan Motivasi Belajar Dan Karakter Semangat Kebangsaan Siswa Kelas V SD. Jurnal Pendidikan Karakter, 1. https://doi.org/10.21831/jpk.v7i1.15498.

Rosdiana, Kusmariyatni, \& Widiana. (2013). Pengaruh Model Pembelajaran Kooperatif Tipe Paired Storytelling Berbantuan Media Audio Visual Terhadap Keterampilan Menyimak Bahasa Indonesia Siswa Kelas V SD. Mimbar PGSD Undiksha, 1(1). http://dx.doi.org/10.23887/jjpgsd.v1i1.826.

Rudiyati, S. (2013). Peningkatan Kompetensi Guru Sekolah Inklusif Dalam Penanganan Anak Berkebutuhan Pendidikan Khusus Melalui Pembelajaran Kolaboratif. Cakrawala Pendidikan, 1(2). https://doi.org/10.21831/cp.v0i2.1488.

Sadikin, A., \& Hamidah, A. (2020a). Pembelajaran Daring di Tenggah Wabah Covid-19. Jurnal Ilmiah Pendidikan Biologi, 6(2), 214-224. https://doi.org/10.22437/bio.v6i2.9759.

Sadikin, \& Hamidah. (2020b). Pembelajaran Daring Di Tengah Wabah Covid-19. BIODIK: Jurnal Ilmiah Pendidikan Biologi, 6(2), 214-224. https://doi.org/10.22437/bio.v6i2.9759.

Saiboon, I. M., MSurg, Nurmaimun, Noriani, Shamsuddin, N. S., \& Johar, M. (2021). Effectiveness of SelfDirected Small-Group-Learning Against Self-Directed Individual-Learning Using Self-InstructionalVideo in Performing Critical Emergency Procedures Among Medical Students in Malaysia: A SingleBlinded Randomized Controlled Study. Clinical Simulation in Nursing, 56(1). https://doi.org/10.1016/j.ecns.2021.02.006.

Salim Nahdi, D., \& Cahyaningsih, U. (2018). Pengembangan Perangkat Pembelajaran Matematika Sd Kelas V Dengan Berbasis Pendekatan Saintifik Yang Berorientasi Pada Kemampuan Pemecahan Masalah Siswa. Jurnal Cakrawala Pendas, 5(1), 1-7. https://doi.org/10.31949/jcp.v5i1.1119.

Santosa, A. D. (2014). Implementasi Pendidikan Karakter dalam Membangun Kemandirian dan Disiplin Siswa di MTsN Kanigoro Kras Kab. Kediri. Dikdaktika Religia, 2(1). http://dx.doi.org/10.30762/didaktika.v2i1.131.

Sidiq, R., \& Najuah. (2020). Pengembangan E-Modul Interaktif Berbasis Android Pada Mata Kuliah Strategi Belajar Mengajar. Jurnal Pendidikan Sejarah, 9(1), 1-14. https://doi.org/10.21009/JPS.091.01.

Suhaida, D., \& Fadillah, S. (2019). Media Kajian Kewarganegaraan membentuk karakter siswa. Jurnal Civics: Media Kajian Kewarganegaraan, 16(2), 111-121. https://doi.org/10.21831/jc.v16i2.21757.

Umbara, I. A. A. P., Sujana, I. W., \& Negara, I. G. A. O. (2020). Model Pembelajaran Problem Based Learning Berbantuan Media Gambar Seri BerpengaruhTerhadap Kompetensi Pengetahuan IPS Siswa. Jurnal Mimbar Ilmu, 25(2), 13-25. http: //dx.doi.org/10.23887/mi.v25i2.25154.

Velan, G. M., Goergen, S. K., Grimm, J., \& Shulruf, B. (2015). Impact of Interactive e-Learning Modules on Appropriateness of Imaging Referrals: A Multicenter, Randomized, Crossover Study. Journal of the American College of Radiology, 12(11). https://doi.org/10.1016/j.jacr.2015.06.026. 
Veronika, A. (2019). Implementasi Ajaran Tri Kaya Parisudha Dalam Membangun Karakter Generasi Muda Hindu Di Era Digital. Jurnal PASUPATI, 6(2). http://dx.doi.org/10.37428/pspt.v6i1.135.

Wati, Darsana, \& Suardika. (2014). Pengaruh Model Pembelajaran Somatic, Auditory, Visual, Intelectual (SAVI) Berbantuan Bahan Ajar Terhadap Hasil Belajar IPS Siswa Kelas V SD Gugus Raden Ajeng Kartini. Mimbar PGSD Undiksha, 2(1). http://dx.doi.org/10.23887/jjpgsd.v2i1.3002.

Widiatmika, D. G., Sujana, I. W., \& Ganing, N. N. (2017). Pengaruh Model Discovery Learning Berbantuan Media Audio Visual Terhadap Kompetensi. MIMBAR PGSD Undiksha, 5(2), 1-8. http://dx.doi.org/10.23887/jjpgsd.v5i2.11786.

Wijayanti, N. P. A., Damayanthi, L. P. E., Sunarya, I. M. G., \& Putrama, I. M. (2016). Pengembangan E-Modul Berbasis Project Based Learning Pada Mata Pelajaran Simulasi Digital Untuk Siswa Kelas X Studi Kasus di SMK Negeri 2 Singaraja. Jurnal Pendidikan Teknologi Dan Kejuruan, 13(2), 184-197. http://dx.doi.org/10.23887/jptk-undiksha.v13i2.8526.

Wulandari, H., \& Purwanta, E. (2021). Pencapaian Perkembangan Anak Usia Dini di Taman Kanak-kanak selama Pembelajaran Daring di Masa Pandemi Covid-19. Jurnal Obsesi : Jurnal Pendidikan Anak Usia Dini, 5(1). https://doi.org/10.31004/obsesi.v5i1.626.

Wulandari, N. P. R., Dantes, N., \& Antara, P. A. (2020). Pendekatan Pendidikan Matematika Realistik Berbasis Open Ended Terhadap Kemampuan Pemecahan Masalah Matematika Siswa. Jurnal Ilmiah Sekolah Dasar Universitas Pendidikan Ganesha, 4(2), 153-164. http://dx.doi.org/10.23887/jisd.v4i2.25103.

Yulisari, S. (2013). Pengaruh Model Pembelajaran Vct Berbantuan Media Power Point Terhadap Hasil Belajar Pkn Siswa Kelas V Sd Gugus V Kecamatan Buleleng. Mimbar PGSD Undiksha, 1(1). http://dx.doi.org/10.23887/jjpgsd.v1i1.719.

Yusuf, M. (2012). Kinerja Kepala Sekolah dan Guru dalam Mengimplementasikan Pendidikan Inklusif. Jurnal Pendidikan Dan Kebudayaan, 18(4). https://doi.org/10.24832/jpnk.v18i4.96

Za'im, M. (2016). Pendidikan Anak dalam Pengembangan Kecerdasan IQ, EQ dan SQ (Studi Kitab Tuhfat Al -Mawdud Bi Ahkam Al- Mawlud Karya Ibnu Al- Qayyim Al- Jauziyah). Muallimuna : Jurnal Madrasah Ibtidaiyah, 2(1). https://doi.org/10.31602/muallimuna.v2i1.743.

Zuliani, D., Florentinus, T. S., \& Ridlo, S. (2017). Pengembangan Instrumen Penilaian Karakter pada Siswa Kelas IV Sekolah Dasar. Journal of Research and Educational Research Evaluation, 6(1). https://doi.org/10.15294/jrer.v6i1.16207. 